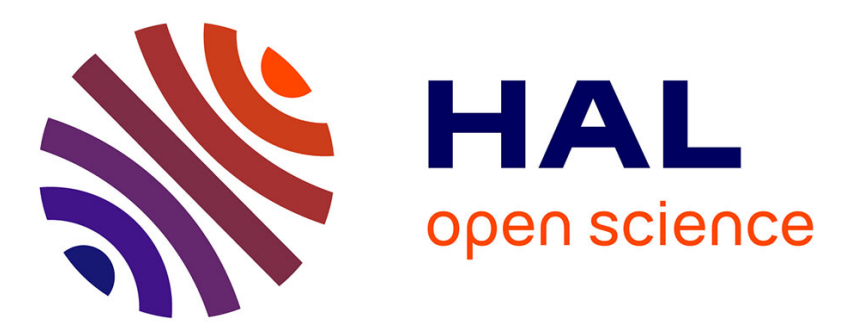

\title{
Evolution of the porous volume during the aerogel-glass transformation
}

T. Woignier, J. Quinson, M. Pauthe, M. Repellin-Lacroix, J. Phalippou

\section{To cite this version:}

T. Woignier, J. Quinson, M. Pauthe, M. Repellin-Lacroix, J. Phalippou. Evolution of the porous volume during the aerogel-glass transformation. Journal de Physique IV Proceedings, 1992, 02 (C2), pp.C2-123-C2-126. 10.1051/jp4:1992213 . jpa-00251284

\section{HAL Id: jpa-00251284 https://hal.science/jpa-00251284}

Submitted on 1 Jan 1992

HAL is a multi-disciplinary open access archive for the deposit and dissemination of scientific research documents, whether they are published or not. The documents may come from teaching and research institutions in France or abroad, or from public or private research centers.
L'archive ouverte pluridisciplinaire HAL, est destinée au dépôt et à la diffusion de documents scientifiques de niveau recherche, publiés ou non, émanant des établissements d'enseignement et de recherche français ou étrangers, des laboratoires publics ou privés. 


\title{
Evolution of the porous volume during the aerogel-glass transformation
}

\author{
T. WOIGNIER, J. F. QUINSON*, M. PAUTHE*, M. REPELLIN-LACROIX* and J. PHALIPPOU \\ Laboratoire de Science des Matériaux Vitreux, Université de Montpellier II, 34095 Montpellier Cedex 5, \\ France \\ ${ }^{*}$ Laboratoire de Chimie Appliquée et Génie Chimique, Université Claude Bernard, Lyon I, \\ 69622 Villeurbanne Cedex, France
}

\begin{abstract}
The evolution of the texture of a silica aerogel during sintering is studied by thermoporometry. During the first stages of the densification the macroporous volume drops strongly while the mesoporous volume seems to be constant. This behavior is in contradiction with sintering models which predict that the sintering rate is faster for bodies with smaller particles or pores. In fact the analysis of the micropore size distribution shows that the sintering of the mesopores is responsible for macropore decrease.
\end{abstract}

\section{INTRODUCTION}

A bulk piece of silica glass can be easily obtained by a simple heat treatment of a monolithic aerogel [1]. Sintering occurs as the temperature is increased. At low temperature a small extended shrinkage appears which is induced by a polycondensation reaction [2]. For temperatures above $950^{\circ} \mathrm{C}$, viscous flow is efficient and allows the aerogel to be fully densified in a very short duration of time. It is obvious that this macroscopic behavior originates from the textural evolution of the aerogel with temperature. For materials exhibiting a large pore size distribution, sintering by viscous flow must act firstly from small size pores [3].

In fact, adsorption-desorption experiments performed on silica aerogels showed that the macropores sinter first and pores of low dimension are not affected in their size at the onset of sintering $[4,5]$.

This very surprising effect was recently confirmed using small angle scattering techniques [6.7.]. A coarsening of pores or a bloating process was assumed to account for the observed phenomenum.

Recently [8] it was proposed that the sintering of the low size pores can drag the macropores and as a consequence induce a decrease in the macropores size.

The present paper deals with the pore variation of aerogels during sintering. The study is performed with thermoporometric measurement which allows the whole range of porosity to be investigated as far as the relative density of the material is known [9]. Moreover, according to IUPAC classification [10], the mesopore size distribution may be calculated.

\section{EXPERIMENTAL}

The silica aerogel, precursor of the densified materials, has been synthesized by a two steps procedure : the formation of a humid gel by hydrolysis and polycondensation reactions of tetramethoxysilane under neutral conditions, followed by the extraction of the liquid above its critical point. The experimental details have been already described in a previous paper [11]. The bulk density of the initial aerogel is $0.18 \mathrm{~g} / \mathrm{cm}^{3}$. The densification is obtained by a set of heat treatments in the temperature range 800 - 
$1000^{\circ} \mathrm{C}$, leading to porous materials with buik density from 0.18 to $0.84 \mathrm{~g} / \mathrm{cm}^{3}$. The bulk density, $d$, is determined by weighting samples with well defined dimensions.

The total porosity, $V_{P}\left(\mathrm{~mm}^{3} / \mathrm{g}\right)$, can be expressed by a simple relationship :

$\mathrm{v}_{\mathrm{P}}=1 / \mathrm{d}_{\mathrm{a}}-1 / \mathrm{d}_{\mathrm{s}}$

In that relation $\mathrm{d}_{\mathrm{S}}$ is the density of the matter, taken equal to 2.2 [12].

$\mathrm{V}_{\mathrm{P}}=\sum_{i} \mathrm{~V}_{\mathrm{Pi}} \quad$ where $\mathrm{V}_{\mathrm{Pi}}$ is the porous volume corresponding

to a family of pores. Then :

$\mathrm{v}_{\mathrm{P}}=\mathrm{v}_{\text {meso }}+\mathrm{v}_{\text {macro }}+\mathrm{v}_{\text {micro }}$

The different pore size ranges are defined as :

$\begin{array}{ll}\text { micropores } & 0-1 \mathrm{~nm} \\ \text { mesopores } & 1-40 \mathrm{~nm} \\ \text { macropores } & >40 \mathrm{~nm}\end{array}$

The mesoporous characteristics (pore size, pore volume and pore size distribution) were measured by thermoporometry. Thermoporometry is a thermal method that analyzes the conditions of solidification of a condensate which saturates the porous material [13]. The microporous volume can also be deduced from thermoporometry data [14].

\section{3 . RESULTS}

In a previous study [9] we have shown that during the supercritical drying process, the microporous texture present in alcogel disappears and no micropores are detected in aerogels. This result is confirmed in this study.

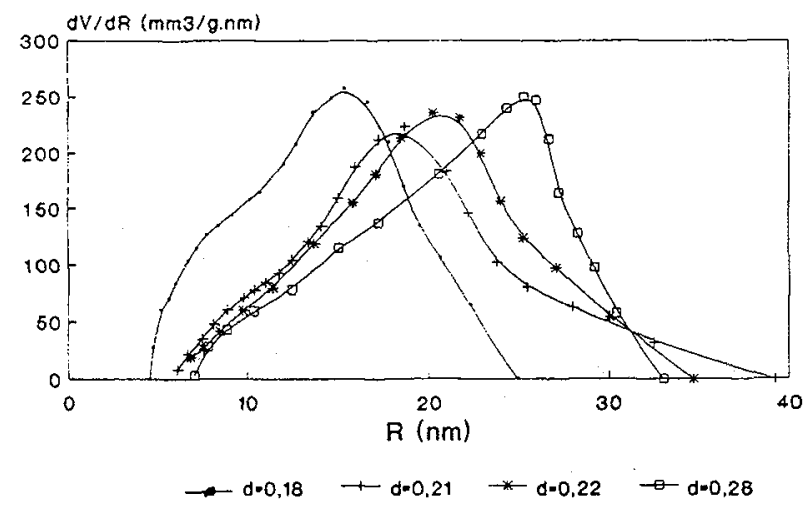

Figure 1 : Mesopore size distribution for different densified aerogels. Density range $0.18-$ 0.26 .

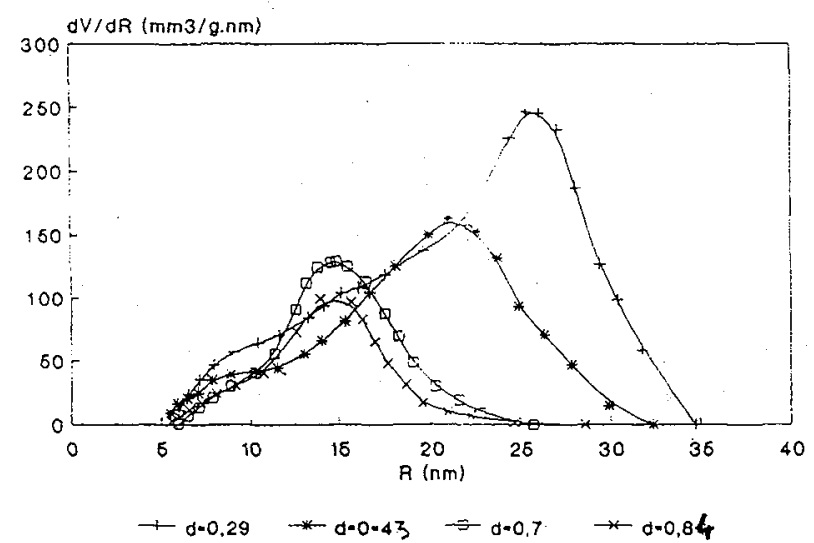

Figure 2 : Mesopore size distribution for different densified aerogels. Density range 0.29 0.84 . 
Table 1 gives the evolution of $V_{\text {meso }}$ and $V_{\text {macro }}$ during the densification. $R_{\max }$ corresponds to the position of the maximum of the mesopore size distribution (Figure 1 and Figure 2) on the pore radius scale.

TABLE 1

\begin{tabular}{|c|c|c|c|}
\hline $\begin{array}{c}\text { density } \\
\mathrm{g} / \mathrm{cm}^{3}\end{array}$ & $\begin{array}{c}\mathrm{R}_{\max } \\
\mathrm{nm}\end{array}$ & $\begin{array}{c}\mathrm{V}_{\text {meso }} \\
\mathrm{mm}^{3} / \mathrm{g}\end{array}$ & $\begin{array}{c}\mathrm{V}_{\text {macro }} \\
\mathrm{mm}^{3} / \mathrm{g}\end{array}$ \\
\cline { 1 - 2 } 0.18 & 15.3 & 2940 & 2110 \\
0.21 & 18.7 & 2880 & 1430 \\
0.22 & 20.2 & 3060 & 1030 \\
0.28 & 25.3 & 3040 & 0 \\
0.29 & 25.3 & 3000 & 0 \\
0.43 & 21.0 & 1930 & 0 \\
0.69 & 14.9 & 990 & 0 \\
0.84 & 14.6 & 750 & 0 \\
\hline
\end{tabular}

\section{DISCUSSION}

The different results must be correlated to follow the textural evolution as a function of temperature.

Figure 3 shows the change of the porous volumes as a function of aerogel density. It appears that the volume of macropores decreases as the density increases. However the mesoporous volume remains constant up to a density close to 0.3 where the macropores disappear.

Because macropores decrease in size, they enter the mesoporous domain. In other words, macropores, in their decrease, contribute partially to the mesoporous volume. However, the fact that the mesoporous volume is constant indicates also that a part of the initial mesopores have disappeared as the sintering proceeds. That contribution of initial macropores to mesopores is confirmed by the change of $R_{\max }$. Figure 4 shows that in the first instants of sintering $R_{\max }$ increases because of the additional volume coming from large pore size. When macropores are totally absent or transformed into mesopores, further sintering indisces then a decrease of the mesopore size.

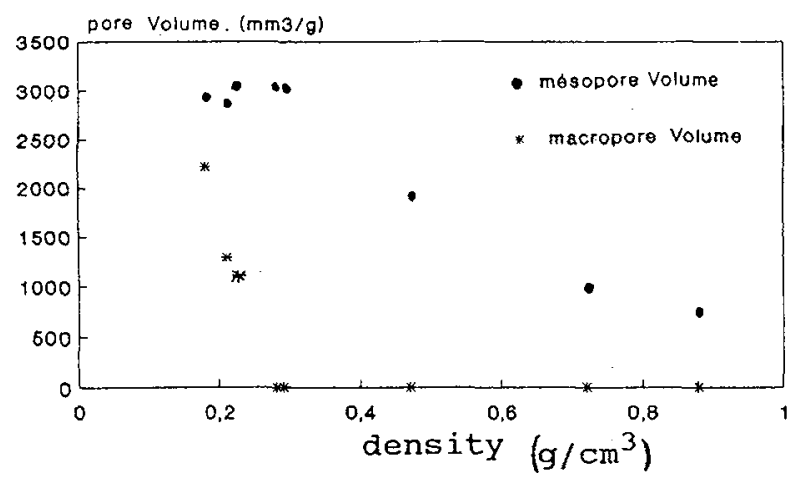

Figure 3 : Mesopore volume and macropore volume evolution during sintering. 


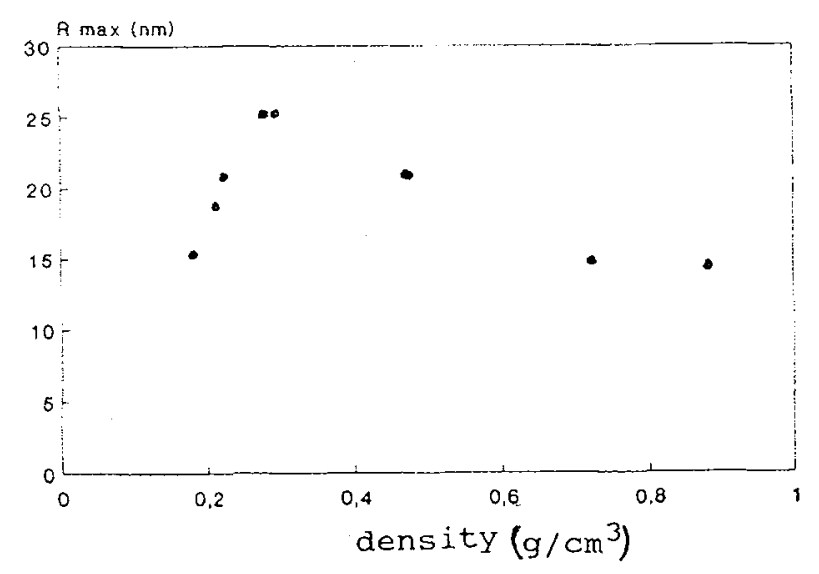

Figure $4: R_{\text {max }}$ evolution during sintering

\section{CONCLUSION}

At the beginning of sintering the pore volume of silica aerogels evolves in a manner which is not expected. The mesoporous volume remains constant while $R_{\text {max }}$ increases. The size of the macropores decreases and thus macropores become mesopores.

A likely explanation is that during heat treatment the smallest pores sinter first, as it is predicted by the viscous flow sintering models [3]. Simultaneously, this local densification induces the shrinkage of the macropores.

The unexpected behavior of the macropores may play a very important role on permeability properties. The ability of partially densified aerogels to be impregnated by active molecules will be dependent on the residual macropores.

\section{6 . REFERENCES}

[1] WOIGNIER, T., PHALIPPOU, J., PRASSAS, M., J. Mat. Sci.; 25 (1990) 3118-3126.

[2] PRASSAS, M., PHALIPPOU, J., ZARZYCKI, J., Science of Ceramic Chemical Processing, Ed. HENCH, L.L., ULRICH, D.R., Wiley, J., chap. 17 (1986) 237.

[3] SCHERER, G.W., J. Amer. Ceram. Soc., 60 (1977) 237.

[4] VAN NORDSTRAND, R.A., KREGER, W.E., RIES Jr, H.E., J. Phys. Colloid Chemistry, 55 (1951) 621-638.

[5] NICOLAON, G.A., TEICHNER, S.J., Bull. Soc. Chim. France, $\underline{5}$ (1968) 1906.

[6] LOURS, T., ZARZYCKI, J., CRAIEVICH, A., J. Non-Cryst. Solids, 95-96 (1987) 1151 1158.

[7] FRICKE, J., J. Non-Cryst. Solids, 121 (1990) 188-192.

[8] SCHERER, G.W., Private communication.

[9] PAUTHE, M., QUINSON, J.F., HDACH, H., WOIGNIER, T., PHALIPPOU, J., SCHERER, G.W., J. Non-Cryst. Solids, 130 (1991) 1-7.

[10] IUPAC, Manuais of Symbol and Terminology, Appendix 2, Part 1, Colloid and Surface Chemistry, Pure Appl. Chem., 31 (1972) 578.

[11] PHALIPPOU, J., WOIGNIER, T., PRASSAS, M., J. Mat. Sci., 25 (1990) 3111.

[12] WOIGNIER, T., PHALIPPOU, J., J. Non-Cryst. Solids, 93 (1987) 17.

[13] BRUN, M., LALLEMAND, A., QUINSON, J.F., EYRAUD, C., Thermochim. Acta, 21 (1977) 59.

[14] DUMAS, J., QUINSON, J.F., SERUGHETTI, J., J. Non-Cryst. Solids, 125 (1990) 244. 